\title{
Eye decoction due to smallpox complications in the Viceroyalty of New Granada in the $18^{\text {th }}$ century
}

\section{Cocimiento para los ojos por complicaciones de la viruela en el Virreinato de la Nueva Granada en el siglo XVIII}

\author{
Eric Y. Canaria-Ascencio ${ }^{1 *}$, Jorge Uribe-Vergara², Julio C. Martínez-Lozano ${ }^{3}$, Alberto Gómez-Gutierrez ${ }^{4}$ \\ and Ignacio Briceño-Balcázar ${ }^{3}$ \\ ${ }^{1}$ Faculty of Medicine, Universidad de La Sabana; ${ }^{2}$ Department of Social Sciences of the Pontificia Universidad Javeriana; ${ }^{3}$ Area of Biosciences, \\ Faculty of Medicine, Universidad de La Sabana; ${ }^{4}$ Institute of Human Genetics, Faculty of Medicine, Pontificia Universidad Javeriana. Colombia
}

\begin{abstract}
Objective: To present an $18^{\text {th }}$ century prescription used in the Viceroyalty of New Granada, which describes the treatment of ocular complications of smallpox, specifying the use of linseed (Linum usitatissimum), saffron (Crocus sativus) and mallow of Castilla (Malva sylvestris) in its preparation. Materials and Methods: Search in the historical archive of the Octavio Arizmendi Posada Library at the University of La Sabana (Chía, Colombia), where a collection of around a hundred prescriptions of the $18^{\text {th }}$ century is preserved; transcribing one of them entitled "Cocimiento para los ojos", with a subsequent review of relevant scientific literature. Conclusions: This colonial prescription shows its usefulness to relieve ocular symptoms of smaIIpox, as an emollient effective for external use, as a clear example of the therapy required. In addition, this prescription should also be recognized as a documentary example of the historical evolution of medicine and the work of herbal medicine, from the colonial times of the then overseas territories of the Spanish Crown.
\end{abstract}

Key words: History of Medicine. Colombia. $18^{\text {th }}$ Century. Smallpox. Eye Disease. Prescriptions.

\section{Resumen}

Objetivo: Presentar una receta médica del siglo XVIII, utilizada en los tiempos del Virreinato de la Nueva Granada, que describe el tratamiento de complicaciones oculares de viruela, especificando el uso de la linaza (Linum usitatissimum), el azafrán (Crocus sativus) y la malva de Castilla (Malva sylvestris) en su preparación. Materiales y métodos: Búsqueda en el archivo histórico de la Biblioteca Octavio Arizmendi Posada, en la Universidad de La Sabana (Chía, Colombia), donde se conserva una colección de un centenar de recetas médicas del siglo XVIII. Se realiza una transcripción de una de ellas, titulada "Cocimiento para los ojos», con una ulterior revisión de la literatura científica pertinente. Conclusiones: Esta receta médica colonial muestra su utilidad para aliviar los síntomas oculares de la viruela, como un efectivo emoliente de uso externo, como un claro ejemplo de la terapéutica necesaria. Además, esta prescripción también debería reconocerse como un ejemplo documental de la evolución histórica de la medicina y la labor de la herbolaria desde los tiempos coloniales de los entonces territorios de ultramar de la Corona española.

Palabras clave: Historia de la Medicina. Colombia. Siglo XVIII. Viruela. Enfermedad Ocular. Prescripciones.

Correspondence:

*Eric Canaria Ascencio

Fac. Medicina. Campus Puente del Común

Km.7, AP. Norte de Bogotá, Chía Date of reception: 04-06-2018

C.P. 50008, Cundinamarca, Colombia Date of acceptance: 31-07-2018

E-mail: ericcaas@unisabana.edu.co_DOI: 10.24875/RMOE.M18000047

0187-4519/O 2018 Sociedad Mexicana de Oftalmología. Publicado por Permanyer México. Est (http://creativecommons.org/licenses/by-nc-nd/4.0/). 


\section{Introduction}

The historical archive of the Octavio Arizmendi Posada library at the Universidad de La Sabana (Chía, Colombia) has a collection of around a hundred colonial medical prescriptions of the eighteenth century, donated by Father Cipriano Rodríguez Santa María, institutional eponym of the archive'.

The arrival of the Spanish explorers and conquerors to the American continent at the end of the $15^{\text {th }}$ century led to a cultural, ethnic and technological exchange-among others-, that changed forever the destiny of millions of people on both sides of the Atlantic Ocean. Among the various elements contributed by the Spaniards to the Americas, there were infectious diseases such as smallpox, which played a major role in modulating the population with a high rate of morbidity and mortality².

Smallpox is a disease caused by a microorganism called Variola ${ }^{3}$ virus, with two varieties, Variola maior and Variola minor, with a demonstrated direct association with a greater or lesser severity of its clinical presentation. It initiates with a prodrome of fever, malaise, headache and body ache, resulting in the occurrence of a maculopapular rash that progresses to pustules and then to crusting ${ }^{4}$.

This disease presents several complications, from mild to severe, being the most common respiratory complications that range from bronchitis to fatal pneumonia, as well as secondary bacterial infections and encephalitis. Additionally, it may induce pustule formation on the eyelids, conjunctiva and cornea leading to conjunctivitis, keratitis, corneal ulcer, iritis, iridocyclitis and optic atrophy, with secondary blindness ${ }^{5}$.

At the end of the eighteenth century, in the then Viceroyalty of New Granada, before the sanitary expedition of the peninsular authorities called "Expedition of the Vaccine"2, smallpox was one of the main health scourges of the old and the new world. By not distinguishing ethnic groups or social status, it had a strong impact on Amerindian indigenous populations, where the highest mortality rate occurred, possibly due to the absence of immunity against the European immigrants. This situation paved the way for Spanish colonial domination after the discovery of America ${ }^{2}$. For this reason, it was necessary at that time to use American preparations to alleviate smallpox complications ${ }^{1}$.

The situation would show signs of improvement with the Royal Philanthropic Expedition of the Vaccine between 1803 and 1806, organized by Francisco Javier Balmis (1753-1819) and José Salvany y Lleopart
(1778-1810) $)^{6}$ and authorized by King Carlos IV of Spain, as a result of the preventive discovery of the famed Edward Jenner (1749-1823) in $1796^{2}$. The Spanish initiative led to the formation of administrative organizations in the American territories of the Spanish empire, such as the "Junta de la Vacuna" in the city of Tunja in New Granada, responsible for immunization. This entity was terminated in $1810^{7}$. We must also emphasize the contributions of José Celestino Mutis (1732-1808) and his nephew Sinforoso Mutis Consuegra (1773-1822) for the disseminated use of the smallpox vaccine in New Granada in the transition from the eighteenth to the nineteenth century ${ }^{8,9}$.

In the meantime, where the smallpox vaccine was not available, its symptoms and complications -specifically ocular- were managed with several medical prescriptions used by colonial physicians, most of them empirical and without academic training. As an example, we show here an original extract of one of these prescriptions in figure $1^{1}$ that is literally transcribed and described below:

\section{Eye decoction}

Linseed and mallow de Castilla leaves, with water from the jar, cooked somewhat slimy; in a little of this cooking, some saffron pieces are poured dry, and if they have no oil, that gives the cooking a color that is not very hot.

If there is no dry saffron, dry it between some papers in the sun, shredding the papers until it dries. With a little of this warm cooking eyes should be washed whenever it is necessary, four or five times a day, or more if necessary.

With the same warm cooking noses and ears should be washed, if they have smallpox inside and there is the need of using them.

The relevance of this article is that it explores and justifies the current understanding of some medications used in the history of ophthalmology. The main objective of our work is to present the context of the formulation of a medical prescription of the eighteenth century in the Viceroyalty of New Granada, which was used to treat the ocular symptoms of smallpox, and to analyze if its ingredients are useful for the improvement of those symptoms.

\section{Materials and methods}

A documentary search was carried out in the historical archive of the Octavio Arizmendi Posada Library at the University of La Sabana, where the prescription 


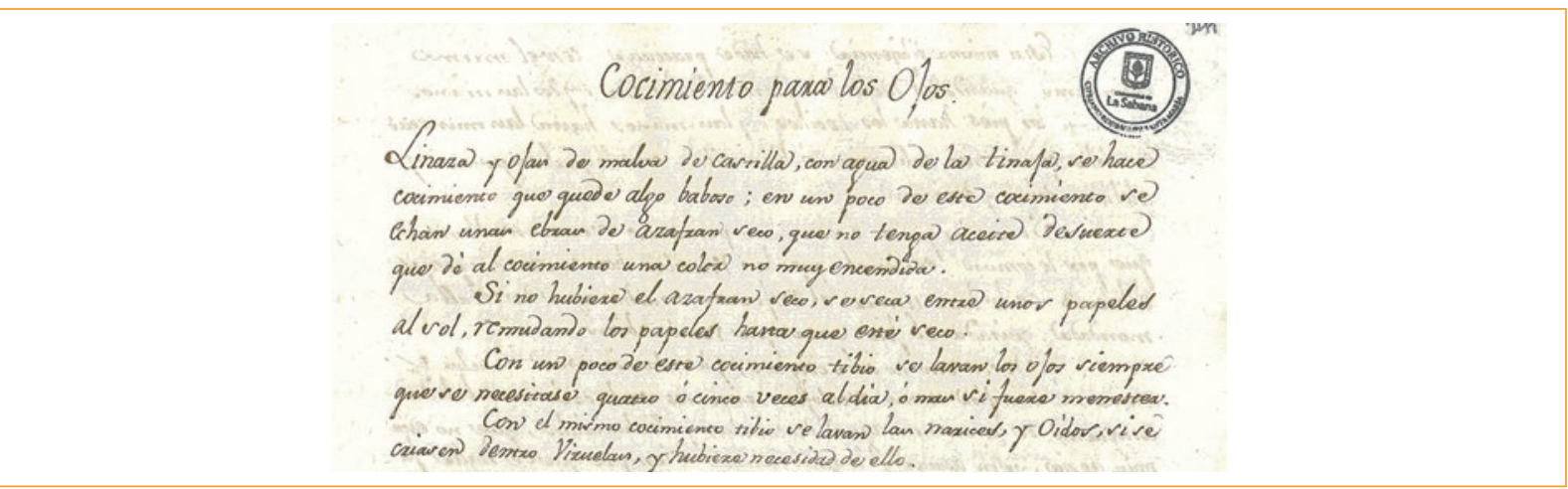

Figure 1. Medical prescription for "eye decoction"1.

"Eye decoction" is found. Secondly, a database review of the available literature on the elements or substances contained in the formula was made.

\section{Analysis of the source document}

The function of this preparation is directly related to the ophthalmological complications described, except optic atrophy for anatomical reasons.

First, it is necessary to define the term "decoction", which, according to the dictionary of the Royal Spanish Academy ${ }^{10}$, refers to "a liquid cooked with herbs or other medicinal substances, which is made for drinking and for other purposes".

So, for the preparation of this prescription the following ingredients are used:

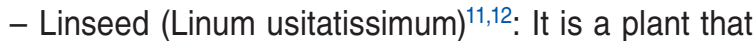
belongs to the family Linaceae, whose stem is used to make textile materials and the seed for diverse medicinal and gastronomic applications. In this case the seed contacts the water producing a viscous ("slimy") liquid, as it is described in the document, as the first component. Consequently, linseed can be identified as an excipient to give shape and volume to the mixture, but also as an emollient (to soften, relax and ease off the inflamed parts).

- Saffron (Crocus sativus) ${ }^{12,13}$ : It is obtained from the pistils of this flower that belongs to the Iridaceae family, whose main uses are as food coloring and flavoring. This condiment has the antecedent of being a product of high commercial interest, with the main crops worldwide located in Iran, Spain, Morocco, India and Greece. Regarding the prescription and considering the current knowledge of this plant derivative, it probably was used only to give color and aroma'.
- Mallow of Castilla (Malva sylvestris) ${ }^{11,12}$ : It is an herbaceous of the Malvaceae family, with medicinal applications. As its taxonomic name indicates, it grows wild and is abundant in areas such as wastelands, cultivation areas, side roads, etc. It is found in Europe, western Asia, northern Africa and in the American continent. Obviously, it was used in the preparation as an emollient.

It is thus observed that the combination of these botanical ingredients, available in the Viceroyalty of New Granada, whether as crops, wild plants or imported elements ${ }^{14}$, was useful for relieving pain and inflammation of the eyes, secondary symptoms of the smallpox infection, as well as for a secondary application in the nasal passages and external auditory canals. It contributed to a symptomatic relief with a clear indication for external use as described in the document. These provisions were regulated by the institution of "protomedicato"15, of peninsular origin, but adapted to the local situation of the time.

A recommendation that would complement this colonial prescription corresponds to the use of boric $\mathrm{acid}^{3}$ due to its antiseptic properties to alleviate associated eye infections as a result of eye rubbing by those affected by smallpox.

\section{Conclusion}

Before concluding, it is important to clarify that smallpox was eradicated in the world according to the World Health Organization in the $1980 \mathrm{~s}^{4}$.

Regarding the colonial medical prescription analyzed in this article, its usefulness for the relief of the ocular symptoms of smallpox could be demonstrated as an effective emollient for external use. It should also be recognized as a documentary example of the historical 
evolution of medicine since the times of the then overseas territories of the Spanish Crown.

The empirical uses of medicinal plants in their respective historical contexts should be considered in order to adequately support the care required in the treatment of the symptoms of diverse current and past conditions, and thus strengthen, through these practices, the tradition of plant and mineral preparations for effective relief. The value of herbal medicine in the history of medicine has been central.

With this analysis, we evidence the praiseworthy effort of the colonial sanitary authorities of the Viceroyalty of New Granada (currently the Republic of Colombia) by using prescriptions like the one described here, with the aim of searching available therapeutics to alleviate the symptoms of incapacitating and adverse conditions, at a time when medical and scientific knowledge was barely in a phase that we now consider primary.

Finally, the effort of the historical archive of the Octavio Arizmendi Posada Library of the Universidad de La Sabana to preserve these documents should be highlighted. These documents have an unquestioned and valuable historical significance, and their consultation allows us to recreate, to a large extent, the evolution of medicine from the eighteenth century to the nineteenth century in the then Viceroyalty of New Granada.

\section{Conflicts of interest}

No conflicts of interest are reported by any author.

\section{Funding}

The research and publication process were funded by the universities to which the authors are affiliated.

\section{Acknowledgements}

The authors acknowledge the generous assistance offered by Marcela Revollo Rueda, director of the Historical Archives of the Octavio Arizmendi Posada Library at the Universidad de La Sabana.

\section{References}

1. Universidad de la Sabana. Archivo Histórico Cipriano Rodríguez Santa María, Fondo Manuel María Mosquera. Caja 10 - Carpeta 2247 recto.

2. Díaz $\mathrm{O}$. La viruela y el hombre. Más allá del humanismo médico. Dendra médica. Revista de Humanidades. 2011;10(1):21-39.

3. Carrada Bravo T. La viruela: diagnóstico, prevención y tratamiento. Piel. 2003;18(5):240-51.

4. Fenner F, Henderson DA, Arita I, Jezek Z, Ladnyi ID. Smallpox and its Eradication Geneva: World Health Organization; 1988.

5. Franco Paredes C, del Río C, Nava Frías M, Rangel Frausto S, Téllez I, Santos Preciado Jl. Enfrentando el bioterrorismo: aspectos epidemiológicos, clínicos y preventivos de la viruela. Salud Pública de México. 2003; 45(4)

6. Balaguer Perigüell E, Ballester Añón R. En El Nombre De Los Niños: La Real Expedición Filantrópica De La Vacuna (1803-1806). Monografías de la Asociación Española de Pediatría; 2003.

7. Gutiérrez Beltrán AC. Las epidemias de viruela en la ciudad de tunja: 1780-1810. La junta de vacuna. Bogotá: Instituto Colombiano de Antropología e Historia ICANH, Area de Historia Colonial; 2007.

8. Palacios Sánchez L. Algunos aspectos relacionados con José Celestino Mutis y la medicina. Revista Ciencias de la Salud. 2008; 6(2).

9. España G. José Celestino Mutis: El sabio de la vacuna. 1.a ed. Bogotá: Colciencias; 1998

10. Diccionario de la lengua española. Real Academia Española. [Online]; 2018. Disponible en: http://dle.rae.es/?id=9angWro.

11. Jiménez R. SL, Fonnegra Gómez R. Plantas medicinales aprobadas en Colombia. 2. ed. Medellín: Editorial Universidad de Antioquia; 2006.

12. Linnaeus CV. Botanicus. [Online]. Holmiae (Estocolmo): Imprensis Laurentii Salvii; 1753. [Edición Original en Latín]. Disponible en: http://www. botanicus.org/title.aspx?bibid=b12069590.

13. Negbi M. Saffron: Crocus sativus L. 1.a ed. Jerusalem: CRC Press; 1999.

14. Pita Pico R. Las boticas en el Nuevo Reino de Granada a finales del periodo colonial: el lento camino hacia la modernidad. Medicina. 2015; 37(3):223-41.

15. Gardeta Sabater P. El Real Tribunal del Protomedicato en la Audiencia de Santa Fe durante la segunda mitad del XVIII: un acercamiento al estudio de las transformaciones de esta institución española.Dynamis: Acta Hispanica ad Medicinae Scientiarumque Historiam Illustrandam. 1992;12:209-24 